JAAKFE UNTAN

(Jurnal Audit dan Akuntansi Fakultas Ekonomi Universitas Tanjungpura)

Vol. 10 No. 1, Juni 2021

ISSN-P: (2252-7486), ISSN-E: (2746-6140)

https://jurnal.untan.ac.id/index.php/jaakfe

\title{
REKONSTRUKSI DAMPAK EKONOMI UMKM KABUPATEN BLITAR DI TENGAH COVID-19
}

\author{
Hery Suprayitno ${ }^{1)} *$, Ratnawan Lukito ${ }^{2)}$, Nurul Farida ${ }^{3)}$ \\ ${ }^{1}$ Universitas Islam Balitar, Indonesia. \\ ${ }^{2}$ Universitas Islam Balitar, Indonesia. \\ ${ }^{3}$ Universitas Islam Balitar, Indonesia. \\ *E-mail: herysuprayitno@unisba.ac.id
}

\begin{abstract}
Abstrak
Tujuan penelitian ini untuk mendeskripsikan kebijakan pemerintah dalam merekontruksi UMKM dari dampak pandemi COVID-19 utamanya di wilayah Blitar. Selain itu, penelitian dimaksudkan untuk memberikan gambaran mengenai strategi apa yang dapat ditempuh sebagai pelengkap kebijakan tersebut. Metode penelitian yang digunakan untuk mengumpulkan data dalam penelitian ini adalah Observasi, dokumentasi, wawancara mendalam (in dept interview). Metode ini digunakan untuk memenuhi tuntutan kebutuhan data sekunder. Metode ini digunakan untuk mencari data-data yang dibutuhkan terutama yang berhubungan dengan data primer yang dianalisa guna untuk Mengkontrusksi realitas. Wawancara tersebut dilakukan dengan berpedoman pada daftar pertanyaan terbuka. Hasil dari peneitian ini adalah upaya yang dilakukan Pemerintah Kabupaten Blitar untuk merekonstruksi dampak ekonomi UMKM di Kabupaten Blitar di tengah pandemic Covid-19 adalah dengan membuka layanan hotline 1500 587, mengajukan stimulus daya beli UMKM dan koperasi, program belanja di warung tetangga untuk menggerakkan ekonomi sekitar, restrukturisasi kredit bunga, memasukkan sektor mikro dalam program kartu prakerja, bantuan langsung tunai, hingga relaksasi pajak untuk UMKM. Selain itu Pemerintah Pusat juga memberikan bantuan berupa dana hibah kepada UMKM terdampak Covid-19 sebesar Rp. 2,4 Juta.
\end{abstract}

Kata kunci: Rekonstruksi; Usaha Mikro, Kecil, dan Menengah; Pandemi Covid-19

Article History: Received:03-06-2021 Revised:08-06-2021 Accepted:10-06-2021 
Vol. 10, No. 1 (Juni 2021)

Hery Suprayitno, Ratnawan Lukito, Nurul Farida

DOI: http://dx.doi.org/10.26418/jaakfe.v10i1.47013

Hal 44-52

\section{PENDAHULUAN}

Penyebaran Corona Virus atau Covid-19 masih menjadi konsen berbagai negara, terutama yang sudah mengonfimasi kasus positif terinfeksi di negaranya. Berdasarkan situs genuine time Coronavirus COVID-19 Worldwide Cases, angka terkait kasus ini terus meningkat. Per tanggal 21 Desember, tercatat sebanyak 76.798 .836 telah terkonfirmasi positif Covid-19 di seluruh wilayah global. Di Indonesia sendiri jumlah pasien positif terinfeksi Virus Corona (Covid-19) disebut bertambah menjadi 664.930 orang. Dari jumlah itu, korban meninggal mencapai 19.880 orang, dengan jumlah yang sembuh 541.811 orang dan masih bertambah terus menerus setiap harinya.

Masih terus mewabahnya Pandemi Virus Corona tentunya memberikan dampak terhadap berbagai sektor. Perekonomian domestik negara-bangsa dan keberadaan UMKM pada tataran ekonomi global merupakan salah satu yang terkena dampak Covid-19 secara signifikan. Laporan Organisation for Economic Co-operation and Development (OECD) menyebutkan bahwa pandemi ini berimplikasi terhadap ancaman krisis ekonomi besar yang ditandai dengan terhentinya aktivitas produksi di banyak negara, jatuhnya tingkat konsumsi masyarakat, hilangnya kepercayaan konsumen, jatuhnya bursa saham yang pada akhirnya mengarah kepada ketidakpastian.

Usaha Mikro Kecil Dan Menengah (UMKM) diakui bahwa memainkan peran penting di dalam pembangunan dan pertumbuhan ekonomi, tidak hanya di negara-negara sedang berkembang, tetapi juga dinegara-negara maju (Tambunan, 2012). Di Indonesia definisi UMKM diatur dalam Undang-Undang Republik Indonsia Nomor 20 Tahun 2008 tentang UMKM. Dalam Bab 1 (Ketentuan Umum), pasal 1 dari UU tersebut, dinyatakan bahwa usaha mikro adalah usaha produktif milik orang-perorangan dan badan usaha perorangan yang memenuhi usaha mikro sebagaimana diatur dalam UU tersebut. Usaha kecil adalah usaha ekonomi produktif yang berdiri sendiri, yang dilakukan oleh orang-perorangan atau badan usaha yang bukan merupakan anak perusahaan atau bukan cabang perusahaan yang dimiliki, dikuasai, atau menjadi bagian baik langsung maupun tidak langsung dari usaha mikro atau usaha besar yang memenuhi kriteria usaha kecil sebagaimana telah diatur dalam UU tersebut.

Keberadaan Usaha Mikro, Kecil, dan Menengah (UMKM) yang mendominasi Indonesia yang sering disebut sebagai tulang punggung perekonomian nasional juga terkena dampak secara serius. Imbas yang di dapat oleh UMKM tidak saja pada aspek total produksi dan nilai perdagangan saja, akan tetapi juga pada jumlah tenaga kerja yang harus kehilangan pekerjaannya karena pandemi sehingga mempengaruhi factor ekonomi mereka.

Menurut Sholahuddin (2007) Ekonomi dikatakan sebagai ilmu yang menerangkan caracara menghasilkan, mengedarkan, membagi serta memakai barang dan jasa dalam masyarakat sehingga kebutuhan materi masyarakat dapat terpenuhi sebaik-baiknya. Kegiatan ekonomi dalam masyarakat adalah mengatur urusan harta kekayaan baik yang menyangkut kepemilikkan, pengembangan maupun distribusi. Menurunnya pendapatan dan ekonomi masyarakat akibat pandemi COVID-19 tentu juga memberikan implikasi negatif bagi 
Vol. 10, No. 1 (Juni 2021)

Hery Suprayitno, Ratnawan Lukito, Nurul Farida

DOI: http://dx.doi.org/10.26418/jaakfe.v10i1.47013

Hal $44-52$

perekonomian domestik seperti penurunan konsumsi dan daya beli masyarakat, penurunan kinerja perusahaan, ancaman pada sektor perbankan dan keuangan, serta eksistensi UMKM.

Rekonstruksi adalah pembangunan kembali semua prasarana dan sarana, kelembagaan pada wilayah pasca bencana, baik pada tingkat pemerintah maupun masyarakat dengan sasaran utama tumbuh dan berkembangnya kegiatan perekonomian, sosial, budaya, tegaknya hukum dan ketertiban, dan bangkitnya peran seerta masyarakat dalam segala aspek kehidupan masyarakat pada wilayah pasca bencana. (Alam, Nurcahyanto, Sulandri, 2020). Rekonstruksi bidang ekonomi adalah pembangunan ekonomi yang menganalisis perkembangan ekonomi yang merupakan fungsi dari faktor-faktor ekonomi dan non ekonomi. Selain itu menurutnya ekonomi pembangunan biasanya disamakan dengan ekonomi pertumbuhan, sedangkan pengertian ekonomi pertumbuhan menganlisis pemerataan ekonomi yang merupakan fungsi dari faktor-faktor ekonomi (Wirasasmita, 2006).

Permasalahan yang dihadapi oleh UMKM menurut Febrantara dan OECD (2021), UMKM dapat dilihat dari sisi penawaran dan sisi permintaan. Dari penawaran, dengan adanya pandemi Covid-19, banyak UMKM mengalami kekurangan tenaga kerja. Hal tersebut terjadi karena alasan menjaga kesehatan pekerja dan adanya pemberlakuan pembatasan sosial (social distancing). Kedua sebab tersebut berujung pada keengganan masyarakat untuk bekerja sementara waktu pandemi masih ada COVID-19. Pada sisi permintaan, berkurangnya permintaan akan barang dan jasa berdampak pada UKM tidak dapat berfungsi optimal yang berujung pada berkurangnya likuiditas perusahaan. Hal ini menyebabkan masyarakat kehilangan pendapatan, karena UKM tidak berkemampuan membayar hak upah pekerja. Pada kondisi terburuk, pemutusan hubungan kerja terjadi secara sepihak.

Penelitian tentang kebijakan rekonstruksi ekonomi pasca bencana memang telah banyak dilakukan. Akan tetapi, penelitian yang banyak dilakukan merupakan penelitian rekonstruksi ekonomi pasca bencana alam. Sedangkan penelitian tentang kebijakan ekonomi pasca bencana non alama belum banyak dilakukan, khsusunya penelitian terkait rekonstruksi ekonomi UMKM dari dampak covid-19. Oleh karena itu, penelitian ini bertujuan untuk mendeskripsikan kebijakan pemerintah dalam merekontruksi UMKM dari dampak pandemi COVID-19 utamanya di wilayah Kabupaten Blitar. Selain itu, penelitian dimaksudkan untuk memberikan gambaran mengenai strategi apa yang dapat ditempuh sebagai pelengkap kebijakan tersebut.

\section{LANDASAN TEORI}

\section{Usaha Mikro, Kecil dan Menengah (UMKM)}

Usaha Mikro Kecil dan Menengah (UMKM) di dedifinisikan sebagai unit usaha produktif yang berdiri sendiri, dilakukan oleh perorangan atau badan usaha di sektor ekonomi. Terdapat perbedaan antara usaha mikro, usaha kecil, usaha menengah, dan usaha besar, perbedaan tersebut umunya didasarkan pada nilai asset awal (bukan termasuk tanah dan bangunan), omset rata-rata per tahun, maupun jumlah pekerja tetap. Akan tetapi definisi 
Vol. 10, No. 1 (Juni 2021)

Hery Suprayitno, Ratnawan Lukito, Nurul Farida

DOI: http://dx.doi.org/10.26418/jaakfe.v10i1.47013

Hal $44-52$

UMKM di tiap Negara berbeda-beda. Maka dari itu, sulit untuk membandikan peran UMKM ditiap Negara (Tambunan, 2012).

Di Indonesia definisi UMKM diatur dalam Undang-Undang Republik Indonsia Nomor 20 Tahun 2008 tentang UMKM. Dalam Bab 1 (Ketentuan Umum), pasal 1 dari UU tersebut, dinyatakan bahwa usaha mikro adalah usaha produktif milik orang-perorangan dan badan usaha perorangan yang memenuhi usaha mikro sebagaimana diatur dalam UU tersebut. Usaha kecil adalah usaha ekonomi produktif yang berdiri sendiri, yang dilakukan oleh orangperorangan atau badan usaha yang bukan merupakan anak perusahaan atau bukan cabang perusahaan yang dimiliki, dikuasai, atau menjadi bagian baik langsung maupun tidak langsung dari usaha mikro atau usaha besar yang memenuhi kriteria usaha kecil sebagaimana telah diatur dalam UU tersebut.

\section{Ekonomi Masyarakat}

Manusia sebagai makhluk social tentu tidak akan dapat terlepas dari kegiatan ekonomi, baik kegiatan distribusi maupun konsumsi. Ekonomi dapat didefinisikan sebagai aktivitas manusia yang berhubungan dengan produksi, distribusi, dan konsumsi barang maupun jasa. Secara khusus ekonomi diartikan sebagai aturan rumah tangga atau manajemen rumah tangga. Menurut Smith dan Osborn (2007) ekonomi disebut sebagai ilmu yang menerangkan caracara menghasilkan, mengedarkan, membagikan serta memakai barang dan jasa dalam masyarakat sehingga kebutuhan masyarakat berupa materi dapat terpenuhi sebaik-baiknya. Kegiatan ekonomi dalam masyarakat merupakan kegiatan dalam mengatur urusan harta kekayaan baik yang menyangkut kepemilikan, pengembangan maupun distribusi.

Ekonomi masyarakat merupakan suatu system ekonomi yang berbasis pada kekuatan ekonomi masyarakat. Dimana ekonomi masyarakat sendiri merupakan sebagian kegiatan ekonomi atau usaha yang dilakukan masyarakat dengan cara swadaya mengelola sumber daya ekonomi apa saja yang dapat diusahakan, yang kemudian disebut sebagai usaha kecil menengah (UKM). Menurut Tambunan (2012) tujuan perekonomian adalah untuk mensejahterakan dan memenuhi kebutuhan hidup masyarakat, serta mencapai kemudahan dan kepuasan. Sehingga akan tercipta kesejahteraan kelangsungan hidup yang produktif.

\section{Rekonstruksi}

Rekonstruksi adalah pembangunan kembali semua prasarana dan sarana, kelembagaan pada wilayah pasca bencana, baik pada tingkat pemerintah maupun masyarakat dengan sasaran utama tumbuh dan berkembangnya kegiatan perekonomian, sosial, budaya, tegaknya hukum dan ketertiban, dan bangkitnya peran seerta masyarakat dalam segala aspek kehidupan masyarakat pada wilayah pasca bencana. (Alam, Nurcahyanto, Sulandri, 2020). Rekonstruksi bidang ekonomi adalah pembangunan ekonomi yang menganalisis perkembangan ekonomi yang merupakan fungsi dari faktor-faktor ekonomi dan non ekonomi. Selain itu menurutnya ekonomi pembangunan biasanya disamakan dengan ekonomi pertumbuhan, sedangkan pengertian ekonomi pertumbuhan menganlisis pemerataan ekonomi yang merupakan fungsi dari faktor-faktor ekonomi (Wirasasmita, 2006). 
Vol. 10, No. 1 (Juni 2021)

Hery Suprayitno, Ratnawan Lukito, Nurul Farida

DOI: http://dx.doi.org/10.26418/jaakfe.v10i1.47013

Hal $44-52$

\section{METODE}

Lokasi penelitian terkait rekontruksi dampak ekonomi UMKM Kabupaten Blitar di lakukan di Desa UMKM yang berada di Desa Rejowinangun, Kecamatan Kademangan, Kabupaten Blitar. Pemilihan lokasi ini dikarenakan di desa tersebut sudah sejak lama di beri label sebagai desa UMKM karena mayoritas kepala keluarga di desa tersebut menjalankan bisnis berupa UMKM.

Penelitian kualitatif dipilih peneliti untuk dijadikan sebagai metode dalam penelitian ini dikarenakan sifat data yang dikumpulkan bercorak kualitatif, tidak di manipulatif, lebih rinci dan aktual dengan melihat masalah dan tujuan penelitian, sedang pendekatannya menggunakan pendekatan interpretive (Smith, dan Osborn, 2007). Selain itu dalam proses penelitian ini diperoleh data deskriptif berupa ucapan, tulisan, dan perilaku dari informan pada lokasi penelitian. Fokus penelitian ini adalah untuk menggali informasi, memahami dan menganalisis pendapat informan tentang dampak ekonomi di tengah covid-19 pada UMKM di Kabupaten Blitar. Informan kunci pada penelitian ini adalah pengusaha UMKM yang berada di Kabupaten Blitar yang terkena dampak Covid-19. Adapun nama-nama informan tersebut adalah:

1. Ibu Sismiati pemilik UMKM Kelapa Jaya yang bergerak di sektor makanan khas Blitar yaitu Geti.

2. Ibu Siti sebagai karyawan di UMKM Cipta Rasa yang bergerak di sektor makanan khas Blitar yaitu jenang dan wajik.

3. Ibu Sumarsih pemilik UMKM Bintang Jaya yang bergerak di sektor makanan khas Blitar yaitu Geti

Dari sisi pengumpulan data, dapat dipisahkan berdasarkan sumber. Sumber data primer diperoleh dari sumber pertama yang berisikan memasukkan pertimbangan-pertimbangan untuk menghasilkan skala prioritas relatif yang dibantu dengan sejumlah daftar pertanyaan. Data sekunder adalah orang atau lembaga yang telah mengumpulkan data, dokumen, laporan dalam jangka waktu tertentu sesuai kebutuhan penelitian.

Metode yang digunakan untuk mengumpulkan data dalam penelitian ini adalah Observasi, dokumentasi, wawancara mendalam (in dept interview) (Sugiyono, 2008). Metode ini digunakan untuk memenuhi tuntutan kebutuhan data sekunder. Metode ini digunakan untuk mencari data-data yang dibutuhkan terutama yang berhubungan dengan data primer untuk mengkontruksi realitas UMKM terdampak Covid.

\section{HASIL DAN PEMBAHASAN}

\section{Dampak Ekonomi UMKM Kabupaten Blitar Akibat Covid-19}

Sejak kemunculan virus Covid-19 di akhir tahun 2019, penyebarannya telah sampai di seluruh dunia. Cepatnya penyebaran virus ini memberikan dampak terhadap ekonomi global yang mulai dirasakan di dalam negeri. Mulai dari bursa saham yang terjun bebas, harga komoditas seperti gas dan minyak sawit yang diperkirakan akan tertarik ke bawah apabila 
Vol. 10, No. 1 (Juni 2021)

Hery Suprayitno, Ratnawan Lukito, Nurul Farida

DOI: http://dx.doi.org/10.26418/jaakfe.v10i1.47013

Hal $44-52$

permintaan tidak segera pulih, serta harga minyak bumi yang jatuh bebas ke bawah (Bahtiar \& Saragih, 2020).

Salah satu industry yang juga terkena dampak dari virus Covid-19 adalah industry pariwisata. Aktivitas wisata di Kabupaten Blitar sempat berhenti beroperasi atau tutup pada bulan Maret 2020 dan baru bisa dibuka pada bulan Agustus 2020. Penutupan wisata ini berlangsung sampai ada izin dari Dinas Pariwisata Kabupaten Blitar (Apsari, Billah \& Insani, 2020).

Penutupan sejumlah kawasan pariwisata di Kabupaten Blitar memiliki efek domino terhadap sektor UMKM. Karena banyaknya wisata yang tutup mengakibatkan pemilik usaha UMKM di bidang makanan kesulitan untuk mendistribusikan dan menjual dagangan mereka. Hal ini sesuai dengan apa yang dipaparkan oleh Ibu Sismiati selaku pemilik UMKM Kelapa Jaya yang bergerak di sektor makanan,

“...ya kan biasanya saya itu kalau kirim geti di tempat wisata-wisata atau di toko oleholeh to mbk, ya semenjak ada corona wisata tutup, tokonnya juga sepi, jadi pesanan itu berkurang banyak. Bahkan sama sekali gak bisa produksi karna gak ada yang pesan...." (Wawancara, 29 Mei 2021)

Hal ini juga di dukung oleh pernyataan Ibu Sumarsih,

“...biasanya seminggu sekali itu saya kirim ke luar kota di Tulungagung dan Kediri, tapi semenjak ada pandemi gak bisa ke luar Kota, karena ya gak ada pesanan, barang yang sudah disana banyak yang gak laku..." (Wawancara, 29 Mei 2021).

Berdasarkan data yang diolah oleh P2E LIPI dalam penelitian Bahtiar \& Saragih (2020) diketahui bahwa dampak penurunan pariwisata terhadap UMKM yang bergerak dalam bidang usaha makanan dan minuman mikro mencapai $27 \%$. Kemudian dampak terhadap usaha kecil makanan dan minuman sebesar $1,77 \%$, dan usaha menengah berada di angka $0,07 \%$. Padahal selama ini dalam perekonomian Indonesia, Usaha Mikro Kecil dan Menengah (UMKM) memiliki peran yang strategis. Dilihat dari data Kementerian Koperasi dan Usaha Kecil dan Menengah Indonesia, pada tahun 2018 menunjukkan jumlah unit usaha UMKM 99,9\% dari total unit usaha atau 62,9 juta unit (kemenkop dan UMKM, 2018).

Selama ini UMKM telah membuktikan kemampuannya untuk bertahan dalam situasi ekonomi yang sulit. Dalam masa krisis Usaha Mikro Kecil dan Menengah (UMKM) terbukti menjadi katup pengaman perekonomian nasional dan merupakan kelompok pelaku ekonomi terbesar dalam perekonomian Indonesia, serta menjadi dinamisator pertumbuhan ekonomi pasca krisis (Singgih, 2007). Maka dari itu, diperlukan perhatian lebih dari pemerintah Kabupaten Blitar kepada sektor UMKM sebagai penggerak utama perekonomian bangsa.

\section{Rekonstruksi Dampak UMKM Kabupaten Blitar}

Dampak dari pandemi virus Covid-19 pada pertumbuhan ekonomi secara global maupun nasional mengalami tantangan yang cukup serius. Angka kemiskinan dan pengangguran di sebagian besar wilayah terdampak Covid-19 semakin meningkat. Selain itu, dunia usaha khususnya Usaha Mikro Kecil dan Menengah (UMKM) juga mengalami dampak 
Vol. 10, No. 1 (Juni 2021)

Hery Suprayitno, Ratnawan Lukito, Nurul Farida

DOI: http://dx.doi.org/10.26418/jaakfe.v10i1.47013

Hal $44-52$

yang serius dari sisi produksi, pemasaran hingga pembiayaan. Seperti halnya yang diungkapkan oleh Ibu Siti selaku pegawai di UMKM Cipta Rasa, yaitu sebagai berikut :

“...semenjak ada virus covid produksi jenang dan wajik tutup mbk, saya juga jadinya nagnggur kerja srabutan yang lain, la yo gimana gak ada yang pesen, orang mantenan yo gak boleh rame-rame otomatis yang biasanya rame pesen wajik dan jenang buat asulasul manten jadi gak ada" (Wawancara, 29 Mei 2021)

Berdasarkan hasil survey, sebanyak $96 \%$ pelaku usaha mengaku sudah mengalami dampak negative Covid-19 terhadap proses bisnisnya. Di antaranya sebanyak $75 \%$ mengalami dampak penurunan penjualan yag signifikan. Sebanyak $67 \%$ pelaku usaha mengalami ketidakpastian dalam memperoleh akses dana darurat, dan sebanyak $75 \%$ kurang mengerti bagaimana cara membuat kebijakan di masa krisis (Soetjipto, 2020).

Sebagai upaya untuk mengatasi hal tersebut, Pemerintah Kabupaten Blitar berupaya melakukan rekontruksi guna mengatasi dampak ekonomi UMKM, Kementerian Koperasi dan UKM telah membuka layanan hotline 1500587 yang ditujukan sebagai tempat aduan bagi UMKM maupun UKM yang usahanya terkena dampak pandemi Covid-19 ini mulai pertengahan Maret 2020. Pendataan ini kemudian menjadi acuan dari pemerintah untuk menyiapkan program-program antisipasi dampak Covid-19, antara lain mengajukan stimulus daya beli UMKM dan koperasi, program belanja di warung tetangga untuk menggerakkan ekonomi sekitar, restrukturisasi kredit bunga, memasukkan sektor mikro dalam program kartu prakerja, bantuan langsung tunai, hingga relaksasi pajak untuk UMKM. Dimana pemerintah berharap program ini bisa membantu koperasi dan UMKM bertahan di masa pandemi ini.

Untuk mengatasi melemahnya sektor UMKM di Kabupaten Blitar Pemerintah Kabupaten Blitar terus berupaya melakukan pemulihan ekonomi ditengah Pandemi Covid-19 di Kabupaten Blitar. Pemerintah Kabupaten Blitar mengakui adanya dampak besar selama Pandemi Covid-19 di sektor Usaha Mikro, Kecil dan Menengah di Kabupaten Blitar, sehingga akan dilakukan upaya pemulihan salah satunya yaitu melanjutkan program Kementerian Koperasi dengan mendata Usaha Mikro Kecil dan Menengah (UMKM) yang ada di Kabupaten Blitar. Dari hasil pendataan kepada para pelaku Usaha Mikro Kecil dan Menengah di Kabupaten Blitar kedepannya para pelaku Usaha Mikro Kecil dan Menengah akan mendapatkan hibah dari Pemerintah Pusat senilai Rp 2,4 juta (Bhiwara, 31 Mei 2021)

Hal ini dibenarkan oleh Ibu Sismiati, sebagai berikut :

“... bulan Juni kemarin pernah disuruh ngisi data UMKM terus sekitar 2 mingguan dananya cair kalau gak salah 2 Juta lebih..." (Wawancara, 29 Mei 2021).

Selanjutnya dari data Usaha Mikro Kecil dan Menengah (UMKM) yang telah dikirim ke Kementerian, akan diverifikasi oleh pihak kementerian, dimana tujuan utama pemberian hibah kepada Usaha Mikro Kecil dan Menengah (UMKM) tak lain agar usahanya bisa berkembang kembali ditengah Pandemi Covid-19.

Ibu Sumarsih menambahkan :

"tapi gak semua dapat mbk, yang ikut daftar di kantor desa ya dapat, kalau yang gak ikut ya gak dapat..” (Wawancara, 29 Mei 2021) 
Vol. 10, No. 1 (Juni 2021)

Hery Suprayitno, Ratnawan Lukito, Nurul Farida

DOI: http://dx.doi.org/10.26418/jaakfe.v10i1.47013

Hal 44-52

Untuk kewenangan menetapkan Usaha Mikro Kecil dan Menengah (UMKM) yang berhak mendapat hibah adalah Pemerintah Pusat, dimana hanya Usaha Mikro Kecil dan Menengah (UMKM) yang memenuhi syarat saja yang akan mendapatkannya, seperti mempunyai Nomor Induk Berusaha (NIB).

\section{SIMPULAN DAN SARAN}

Pemerintah Kabupaten Blitar telah mengeluarkan beberapa kebijakan guna merekontruksi dampak ekonomi UMKM di Kabupaten Blitar di tengah pandemic Covid-19 yaitu dengan membuka layanan hotline 1500 587, mengajukan stimulus daya beli UMKM dan koperasi, program belanja di warung tetangga untuk menggerakkan ekonomi sekitar, restrukturisasi kredit bunga, memasukkan sektor mikro dalam program kartu prakerja, bantuan langsung tunai, hingga relaksasi pajak untuk UMKM. Selain itu Pemerintah Pusat juga memberikan bantuan berupa dana hibah kepada UMKM terdampak Covid-19 sebesar Rp. 2,4 Juta.

Dewan Pemerintahan di Kabupaten Blitar dengan fungsi pengawasannya perlu mendorong pemerintah untuk memanfaatkan keunggulan geografis untuk dijadikan peluang apabila pemerintah membangun titik-titik UMKM di daerah bebas Covid-19, terutama apabila bertujuan ekspor. Selain itu, pemerintah juga perlu memberikan stimulus berupa pengurangan tarif listrik, penurunan harga BBM, menjamin ketersediaan bahan produksi seperti bahan baku supaya kegiatan usaha UMKM tidak terganggu secara signifikan dan mampu kembali ke tingkta produksi normalnya.

\section{DAFTAR PUSTAKA}

Apsari, R. W., Billah, E. N., \& Insan, N. (2020). Dampak Covid-19 Terhadap Pengelolaan Agrowisata Perkebunan Teh Sirah Kencong Kabupaten Blitar sebagai Obyek Wisata Berkelanjutan. EDUTOURISM Journal Of Tourism Research, 2(02), 61-72.

Bahtiar, R. A., \& Saragih, J. P. (2020). Dampak Covid-19 terhadap perlambatan ekonomi sektor umkm. Jurnal Bidang Ekonomi Dan Kebijakan Publik, 7(6), 19-24.

Beik, I. S., \& Arsyianti, L. D. (2019). Ekonomi Pembangunan Syariah. PT RajaGrafindo Persada.

Bungin, B. (2019). Metodologi penelitian kualitatif: Aktualisasi metodologis ke arah ragam varian kontemporer

Creswell, J. W., W. E. Hanson., V. L. P. Clark., dan A. Morales. (2007). Qualitative Research Designs : Selection and Implementation. The Counseling Psychologist. Vol 35, No 2. March. Pp 236 -264

Deliarnov. (2009). Perkembangan Pemikiran Ekonomi. Jakarta: Rajawali Pers

Departemen Pendidikan Nasional. (2001), Kamus Besar Bahasa Indonesia. Jakarta: Balai Pustaka.

OECD. "SME Policy Responses." Diakses 19 Januari 2021. https://read.oecdilibrary.org/view/?ref=119_119680-di6h3qgi4x\&title=Covid-

19_SME_Policy_Responses.

Sholahuddin, M. (2007). Asas-Asas Ekonomi Islam. Jakarta: PT. Raja Grafindo Persada. 
Vol. 10, No. 1 (Juni 2021)

Hery Suprayitno, Ratnawan Lukito, Nurul Farida

DOI: http://dx.doi.org/10.26418/jaakfe.v10i1.47013

Hal 44-52

Singgih, M. N. (2007). Strategi Penguatan Usaha Mikro Kecil Menengah (UMKM) Sebagai Refleksi Pembelajaran Krisis Ekonomi Indonesia. Jurnal Ekonomi Modernisasi, 3(3), 218-227.

Smith, J. A., dan M. Osborn. (2007). Interpretative Phenomenological Analysis.

Soetjipto, N. (2020). Ketahanan UMKM Jawa Timur Melintasi Pandemi Covid-19.

Sugiyono, (2008). Metode Penelitian Kunatitatif Kualitatif dan R\&D. Bandung Alfabeta

Tambunan, T. (2012). UMKM Indonesia. BUKU DOSEN-2014.

Undang-Undang Republik Indonsia Nomor 20 Tahun 2008 tentang UMKM.

Wirasasmita, Yuyun. (2006). Aspek-aspek Ekonomi Mikro Perusahaan Kecil Tradisional Keluarga, Universitas Padjajaran.

https://www.harianbhirawa.co.id/dampak-covid-19-pemkab-blitar-usulkan-usaha-mikrodapat-hibah-rp24-juta/ (diakses, 31 Mei 2021) 